\title{
Preliminary investigation of the influence of housing types on reproductive characteristics of snail (Achatina achatina)
}

\author{
Mogbo Tochukwu Chinedu ${ }^{1,}$,, Okeke John Joseph ${ }^{1}$, Ufele Angela Nwogor ${ }^{1}$, \\ Nwosu Moses Chukwuemeka ${ }^{2}$, Ibemenuga Keziah Nwamaka ${ }^{2}$ \\ ${ }^{1}$ Department of Zoology, Nnamdi Azikiwe University, Awka, Nigeria \\ ${ }^{2}$ Department of Biological Science, Anambra State University, Uli, Nigeria
}

\section{Email address:}

mogbotoochi@yahoo.com(Mogbo T. C.)

\section{To cite this article:}

Mogbo Tochukwu Chinedu, Okeke John Joseph, Ufele Angela Nwogor, Nwosu Moses Chukwuemeka, Ibemenuga Keziah Nwamaka. Preliminary Investigation of the Influence of Housing Types on Reproductive Characteristics of Snail (Achatina Achatina). American Journal of BioScience. Vol. 1, No. 4, 2013, pp. 54-58. doi: 10.11648/j.ajbio.20130104.11

\begin{abstract}
Most efforts towards boosting reproduction in snails are directed towards nutrition and soil composition and little emphasis have been placed in exploring other factors that might influence reproduction in snails. The influence of housing types on reproductive characteristics of Achatina achatina was investigated with ninety juvenile snails subjected to each of the three housing treatments in replicates of 15 snails per replicate for 36 weeks. The housing treatments had the same dimensions $(120 \mathrm{~cm}$ x $60 \mathrm{~cm} \times 30 \mathrm{~cm})$ and were labeled as: - Treatment A (Hutch box), Treatment B (Trench pen) and Treatment $\mathrm{C}$ (Mini-paddock pen). The housing treatments and its surroundings were fitted with a digital thermometer and hygrometer to take daily readings of internal and ambient temperature and humidity. The snails in each replicate were fed daily rations of $60 \mathrm{~g}$ of dry Guinea corn bran, $50 \mathrm{~g}$ ground egg shell and water was also supplied. The reproductive parameters investigated were egg production and hatchability of eggs. Other parameters investigated were temperature and humidity variations. There was no significant difference $(\mathrm{P}>0.05)$ in the means of the reproductive parameters even though the highest yield of egg production and hatchability of eggs were observed in snails subjected to Treatment $\mathrm{C}$. The temperature variation was lowest in Treatment $\mathrm{C}\left(4.0^{\circ} \mathrm{C}\right)$ and highest in Treatment $\mathrm{B}\left(6.9^{\circ} \mathrm{C}\right)$. The humidity variation was also lowest in Treatment C (14.5\%) and highest in Treatment B (15.9\%). The study recommends that any of the housing treatments can be used as laying pens for Achatina achatina since housing has no significant influence on their reproductive characteristics.
\end{abstract}

Keywords: Housing, Reproduction, Achatina Achatina, Snail

\section{Introduction}

Snail meat is a high quality food that is rich in protein, low in fats and source of iron (Orisawuyi, 1989) calcium, magnesium and zinc (Ademolu et al., 2004); hence it is used in the treatment of anemia and hypertension (Ejidike, 2001). The high calcium content and polyunsaturated fatty acid of snail meat is the reason why it is recommended for cases of rickets ( $\mathrm{Su}$ et al., 2004). Imevbore and Ademosun in 1988 accessed the nutritive value of snail meat and observed that it has a protein content of $88.37 \%$. This value compares favourably with conventional animal protein sources whose value ranges from $82.42 \%$ (pork) to $92.75 \%$ (beef). Snail meat contains $70 \%$ of water while its dry matter is high in essential amino acids such as lysine, leucine, arginine, tryptophan and also 30\% minerals (Akinnusi, 1998). Snail is also a source of calcium orthophosphate which is a chemical substance for curing kidney diseases (Imevbore and Ademosun, 1988). Their rich level of mineral salt, Iron and Iodine, position snails as a recommended regular delicacy for pregnant and nursing mothers. (Ajayi et al., 1978). Poor lipid content of snail makes it to be about the only meat apart from fish to be recommended for liver-diseased patients, arteriosclerosis, stroke and asthma patients. It is also recommended for diabetic and hypertensive patients (Akinnusi, 2002). 
Internationally, snail meat commands good market in Europe and North America (Awah, 2000). The French snail requirement is about 5 million $\mathrm{kg} / \mathrm{annum}$ out of this; more than $60 \%$ is imported. Italy is said to consume about 306 million $\mathrm{kg}$ of snails annually. In West Africa, Cote D'ivore has an estimated annual snail consumption of 7.9 million $\mathrm{kg} /$ annum. Although the annual snail consumption figure for Nigeria is not known, it is certain that the demand is far ahead of supply (Awah, 2000). Besides, it commands high price in the restaurants and markets than other conventional meat such as beef, chevron and pork in Nigeria (Okon et al., 2009 and Omole, 2010). The low capital and simple management practices involved have also drawn the attention of many farmers to snail farming.

Snails are cold-blooded (FAO, 1991). They thrive best in areas with moderate temperature and high humidity. In West Africa, temperatures in the areas where most edible species are found do not fluctuate greatly. (Jess and Marks, 1998). However, there are significant fluctuations in air humidity, which have a pronounced effect on the reproductive characteristics of snails (Ebenso, 2006). Relative air humidity should not be near saturation, because it would encourage the development of harmful bacteria and fungi (Cobbinah et al., 2008). In outdoor situations, it is clearly impossible to control climatic factors and this is the major problem faced by snail farmers in Africa. The high cost of adequate climate control facilities for snail production in Africa necessitates that researches should be conducted to find alternative sources of climate modification other than the conventional expensive ones to boost production in snails, hence the relevance of this work.

This study is aimed at investigating the influence of housing types on egg production and hatchability of Achatina achatina.

\section{Materials and Methods}

\subsection{Study Area}

The study was carried out in MOGBO's Farm in Amawbia in Awka South Local Government Area, Anambra State of Nigeria. Amawbia is a town located between latitude $6^{0} \mathrm{~N}$ and $7^{0} \mathrm{~N}$ and longitude $7^{0} \mathrm{~N}$ and $8^{0} \mathrm{~N}$. Ecologically, it lies in the Guinea savanna experiencing an annual rainfall of $1000 \mathrm{~mm}-1500 \mathrm{~mm}$ with two seasons the dry and rainy season.

The farm had an area of $105 \mathrm{~m}^{2}(15 \mathrm{~m} \mathrm{x} 7 \mathrm{~m})$ and each of the housing treatments were placed in roofed enclosures and protected from direct rain and sunlight. Each enclosure was roofed with aluminum roofing sheets and padded with ceiling. There were plantain trees and rich vegetation around the farm to minimize wind effect. This was done to improve the microclimate of the snails as recommended by Cobbinah et al., (2008). The Intensive system of snail farming was used and the snails were provided with food and water in a closed system throughout the study period.

\subsection{Experimental Design}

The study lasted for 36 weeks. Ninety juvenile Achatina achatina snails were used for the study and they were subjected to three different housing types each with dimensions $(120 \mathrm{~cm} \times 60 \mathrm{~cm} \times 30 \mathrm{~cm})$ in replicates of 15 snails per replicate; This is in line with the standard stocking density proposed by Cobbinah et al. (2008) The housing treatments were labeled thus: Hutch box (Treatment A), Trench pen (Treatment B) and Mini Paddock Pen (Treatment C). The housing treatments were each filled with soil rich in humus to a depth of $10 \mathrm{~cm}$ to serve as bedding material and provide a soft substrate for the snails. The soil was changed every 3 months to prevent over fouling by snail droppings and mucus secretions. Each housing treatment and its surrounding were fitted with a digital thermometer and hygrometer to take daily temperature and humidity readings and the battery of the instrument was replaced every two months.

The snails in all the treatments were subjected to the same management conditions: they were fed daily rations of $60 \mathrm{~g}$ Guinea corn bran, they were provided with humus soil to a depth of $10 \mathrm{~cm}$ and were fed $50 \mathrm{~g}$ of ground egg shell as calcium source to ensure shell length and same amount of water ( 0.75 liter) was sprinkled daily to increase humidity and prevent hibernation as done by Agbogidi (Agbogidi et al., 2008). Fresh water was also supplied.

When egg production started $\left(29^{\text {th }}\right.$ week $)$ eggs were collected from each of the housing treatments once daily (7:00 am in the morning) for eight (8) weeks and were transferred to an empty house of same type and buried at a depth of $3 \mathrm{~cm}$ in the soil in clutch sizes of 10 eggs per clutch using the methods of Ugwu (Ugwu et al., 2011). The clutch size of ten was also selected to help reduce cannibalism of hatchlings since high densities of clutches of egg masses increase the rate of cannibalism (Beeby and Richmond, 2001). A total of 100 fertile eggs were introduced in each housing treatment to observe hatchability. The fertility of the eggs was determined by candling the eggs in a dark room with very bright flash light using the methods of Ugwu (Ugwu et al., 2011). Fifty grams $(50 \mathrm{~g})$ of ground egg shell was introduced to the soil to act as calcium source and discourage cannibalism since hatchlings have a craving for calcium and would eat other eggs if they hatch first.

\subsection{Data Collection and Analysis}

The total number of eggs laid by snails per housing treatment was recorded; the hatchability of eggs was recorded and determined thus:

$$
\text { Hatchability }(\%)=\frac{\text { Number of eggs that hatched } \times 100}{\text { Total number of fertile eggs } 1}
$$

Daily readings were also obtained from the thermometer and hygrometers. Hibernation and mortality was also recorded for the snails. The means of the reproductive indices were statistically analyzed with ANOVA using Excel (2007) at 5\% level of significance. 


\section{Result}

Egg production started in the $29^{\text {th }}$ week of the research and the distribution of egg in weeks is presented in table 1. The highest egg production was observed in treatment $\mathrm{C}$ while the least was observed in treatment B (table 1). The egg production showed no significant difference $(\mathrm{P}>0.05)$. Similarly, the highest hatchability of egg was also recorded in snails subjected to treatment $\mathrm{C}$ (table 2) and there was also no significant difference $(\mathrm{P}>0.05)$ in the egg hatchability. The mortality and hibernation observed throughout the study is reported in table 3 . Snails subjected to treatment $\mathrm{C}$ had the least mortality and hibernation compared to other housing treatments. Table 4 and 5 presents the variation in temperature and humidity respectively. The least temperature (table 4) and humidity (table 5) variation was observed in Treatment $\mathrm{C}$.

Table 1: Egg production in snails (Achatina achatina) subjected to housing treatments

\begin{tabular}{|c|c|c|c|c|c|c|c|c|c|c|}
\hline Treatments & Replicates & Wk 29 & Wk 30 & Wk 31 & Wk 32 & Wk 33 & Wk 34 & Wk 35 & Wk 36 & total \\
\hline \multirow{2}{*}{$\mathbf{A}$} & A3 & 6 & 9 & 12 & 18 & 11 & 8 & 5 & 9 & \multirow{2}{*}{108} \\
\hline & A4 & - & 4 & 5 & 7 & 4 & 0 & 6 & 4 & \\
\hline \multirow{2}{*}{ B } & B3 & 5 & - & 7 & 12 & 6 & 8 & 9 & 9 & \multirow{2}{*}{101} \\
\hline & B4 & 12 & 9 & 6 & 5 & 7 & - & - & 6 & \\
\hline \multirow{2}{*}{ C } & $\mathrm{C} 3$ & 6 & 18 & 6 & 12 & 12 & 4 & 11 & 4 & \multirow{2}{*}{121} \\
\hline & $\mathrm{C} 4$ & 7 & 4 & 9 & - & 5 & 6 & 8 & 9 & \\
\hline
\end{tabular}

Table 2: Egg hatchability of snails (Achatina achatina) subjected to housing treatments.

\begin{tabular}{ccccc}
\hline Treatments & Total No of eggs & No hatched & No unhatched & Hatchability (\%) \\
\hline A & 100 & 56 & 44 & $56^{\text {a }}$ \\
B & 100 & 57 & 43 & $57^{\text {a }}$ \\
C & 100 & 61 & 39 & $61^{\text {a }}$ \\
\hline
\end{tabular}

Figures in the same column having the same superscript are not significantly different $(\mathrm{p}>0.05)$

Table 3: Mortality and hibernation in snails subjected to three housing treatments

\begin{tabular}{cccc}
\hline Treatments & Mortality & Hibernation \\
\hline A & 5 & 16 \\
B & 3 & 10 \\
C & 3 & 7 \\
\hline
\end{tabular}

Table 4: Average maximum and minimum temperatures in the housing treatments, environment and temperature variation

\begin{tabular}{|c|c|c|c|c|c|}
\hline Treatments & $\begin{array}{l}\text { Min. average temp } \\
\left(C^{0}\right)(a)\end{array}$ & $\begin{array}{l}\text { Max. average temp } \\
\left(C^{0}\right)(b)\end{array}$ & $\begin{array}{c}\text { Min. average } \\
\text { ambient temp }\left(C^{0}\right)\end{array}$ & $\begin{array}{c}\text { Max. average } \\
\text { ambient temp }\left(C^{0}\right)\end{array}$ & $\begin{array}{cc}\text { Temp variation } & \text { (b } \\
-\mathbf{a}) & \\
\end{array}$ \\
\hline $\mathbf{A}$ & 23.0 & 29.0 & 22.6 & 31.5 & 6.0 \\
\hline B & 22.4 & 29.3 & 22.6 & 31.5 & 6.9 \\
\hline C & 22.7 & 27.6 & 22.6 & 31.5 & 4.9 \\
\hline
\end{tabular}

Table 5: Average maximum and minimum humidity in the housing treatments, environment and humidity variation

\begin{tabular}{|c|c|c|c|c|c|}
\hline Treatments & $\begin{array}{c}\text { Min. average humidity } \\
\text { (\%) (a) }\end{array}$ & $\begin{array}{c}\text { Max. average } \\
\text { humidity (\%) (b) }\end{array}$ & $\begin{array}{c}\text { Min. average } \\
\text { ambient humidity } \\
(\%)\end{array}$ & $\begin{array}{c}\text { Max. average } \\
\text { ambient humidity } \\
(\%)\end{array}$ & $\begin{array}{c}\text { Humidity variation } \\
(\mathbf{b}-\mathbf{a})\end{array}$ \\
\hline $\mathbf{A}$ & 75.5 & 90.3 & 73 & 89 & 14.8 \\
\hline B & 76.1 & 92.0 & 73 & 89 & 15.9 \\
\hline C & 75.6 & 90.1 & 73 & 89 & 14.5 \\
\hline
\end{tabular}

\section{Discussion}

All the housing treatments were constructed according to the standards proposed by Cobbinah et al., (2008) for snail production in the tropics. All the housing treatments met the requirements of a good snailery as proposed by
Cobbinah et al., (2008): they were all escape proof and no single snail escaped throughout the study period. The housing treatments were also spacious and met the standard stocking density for snails in the tropics (15-25 snails per square meter). They were very accessible and easy to work in for handling the snails, placing feed, cleaning and other 
tasks. The housing treatments also offered adequate protection to the snails against insects and predators.

Hatchability of egg in snails depends on temperature and humidity (Ugwu et al., 2011). The modification of the ambient temperature and humidity made by the housing treatments (table 4 and 5) was not enough to bring about a significant difference in the means of egg hatchability. Even though Treatment $\mathrm{C}$ showed numerical difference, any of the housing treatments can be used for hatching the eggs of snails. Egg hatchability in snails is also dependent on soil depth and soil type (Ugwu et al., 2011) and controlled environment (Ejidike et al., 2004).

The ground egg shell provided in the soil reduced cannibalism of eggs by hatchling to zero percent $(0 \%)$ and not even a single egg was lost to cannibalism. This is in line with the findings of Beeby and Richmond (2001) who advised the introduction of calcium to eggs to reduce cannibalism. All the eggs in all the housing treatments hatched within one to three days of each other for batches that were laid the same day. This also is an indication that all the housing treatments are conducive for hatchability of eggs as evident in the reports of Beeby and Richmond (2001) who stated that most snail eggs hatch within one to three days of each other provided the eggs are kept at optimum temperature and humidity.

The temperature and humidity (Table 4 and 5) observed in all the housing treatments fall within the optimum range of temperature and humidity for snail production in the tropics as reported by Cobbinah et al., (2008). He reported that temperature above $30^{\circ} \mathrm{c}$ and humidity below $70 \%$ is not adequate for snail production. Neither of the housing treatments had an average temperature that exceeded $30^{\circ} \mathrm{C}$ nor humidity that is below $70 \%$.

\section{Conclusion}

The results of the study revealed that housing does not have a significant influence on egg production and hatchability of Achatina achatina. Though treatment $\mathrm{C}$ showed numerical difference in both egg production and hatchability, any of the housing treatments can be used as laying and hatching pens for Achatina achatina.

\section{Acknowledgement}

The author wish to acknowledge Professor Anizoba Margaret Azuka for supervising this research work and Osadebe Nwanneka for assistance in data collection.

\section{References}

[1] Ademolu, K. O., Idowu, A. B., Matiana, C. F. and Osinowo, O. A. (2004). Performance proximate and mineral analysis of African giant land snail (Archachatina marginata) fed different nitrogenous sources. African Journal of Biotechnology 3 (8): 412 - 417.
[2] Agbogidi, O. M, Okonta, B. C. and Ezeanya, E. L. (2008). Effects of two edible fruits on the growth performance of African giant land snail (Archachatina marginata Swainson) Pakistan Journal of Nutrition 6(2): 201 - 203.

[3] Ajayi, S. S., Fewe, O. O., Moriarty, C. and Awesu M. O. (1978). Observations on the biology and nutritive value of the African Giant snail (Archachatina marginata). Wildlife Journal. 3: 85-95.

[4] Akinnusi, O. (1998). Introduction to snail and snail farming. Omega science publishers, Lagos. 141pp.

[5] Akinnusi, O. (2002). Introduction to snail and snail farming. Triolas Exquisite ventures. Abeokuta. 25pp.

[6] Awah, A. A. (2000). Introduction to Mini-livestock Development as Sustainable Agriculture Business. Workshop paper presented at Anambra State Agricultural Development Programme during Monthly Technology Review. 25pp.

[7] Beeby, A. and Richmond, L. (2001). Calcium provision to eggs in two populations of Helix aspersa by parents fed a diet high in lead. Journal of Molluscan studies. 67(1): 1-6

[8] Cobbinah, J. R., Vink, A. and Onwuka, B. (2008). Snail farming, processing and marketing. Agromisa Foundation, Wayeningen. 78pp.

[9] Ebenso, I. E. (2006). A note on the effects of water on incubating eggs of edible Tropical land snail Limicolaria aurora. Livestock Research for Rural Development. 18 (10): $17-23$.

[10] Ejidike. B. N. (2001) Comparative effect of supplemental and complete diets on the performance of African giant land snail (A. marginata) Proceedings of the $26^{\text {th }}$ Annual Conference of the Nigerian Society for Animal Production. Vol 26: $151-153$.

[11] Ejidike, B. N., Afolayan, T. A. and Alokun, J. A. (2004). Observations on some climatic variables and dietary influence on the performance of cultivated giant land snail (Archachatina marginata): Notes and records. Pakistan Journal of Nutrition. 3 (6): $362-364$.

[12] FAO (1991). African Research Bulletin. Food and Agricultural Organization of The United Nations Rome. Nigerian Livestock Subsector 53pp.

[13] Imevbore, E. and Ademosun, A. A. (1988). The nutritive value of African Giant land snail (Archachatina marginata). Nigerian Journal of Animal production. 15: 109 - 112.

[14] Jess, S. and Marks, R. J. (1998). Effects of temperature and photoperiod on growth and reproduction of snails. Journal of Agricultural Science. 130 (3): 367 - 372.

[15] Okon, B., Ibom, L. A., Williams, M. E. and Akpakpan, I. E. (2009). Comparative evaluation of reproductive performance and some egg quality parametes of black and white skinned snails. Global Journal of Agricultural Sciences Vol 8(1): 77 - 80 .

[16] Omole, A. J. (2010) Performance and Carcass analysis of growing snails fed Calopogonium mucunoides (Calopo) and Pueraria phasioloides (kudzupuero). Nigerian Journal of Animal Production. Vol 37 (1\&2) 85 - 90.

[17] Orisawuyi, Y. A. (1989). Practical guides to snail rearing. 
Gratitude Enterprises, Lagos. 27pp.

[18] Su, X. Q., Antonas, K. N. and Li, D. (2004). Comparison of n-3 polyunsaturated fatty acid content of wild and cultured Australian abalone. International Journal of Food Science and Nutrition. 55 (2): $149-154$.
[19] Ugwu, S. O. C., Ogbu, C. C. and Amaechi, C. C. (2011). Effects of soil type and soil depth on the reproductive performance of two species of giant African land snails in the humid Tropics. International Journal of Science and Nature. 2 (2): 176 - 182. 